DOI: 10.12731/2077-1770-2020-6-63-72

УДК 81'373.46

\title{
СТРУКТУРНЫЕ ОСОБЕННОСТИ ТЕРМИНОПОЛЯ «ВЗЛОМ» В СФЕРЕ ИНФОРМАЦИОННОЙ БЕЗОПАСНОСТИ В АНГЛИЙСКОМ И ИТАЛЬЯНСКОМ ЯЗЫКАХ (СОПОСТАВИТЕЛЬНЫЙ АНАЛИЗ)
}

\section{Долгоновская Л.Я., Новикова И.Н.}

Статья посвящена структурному анализу терминополя «взлом» в сфрере информационной безопасности в английском и итальянском языках. Цель исследования: описать, сравнить основныле структурные особенности изучаемых терминологических единии и выявить наиболее продуктивные модели.

Методы исследования. Исследуемые терминологические единицьь были определены методом сплошной выборки из научных журналов по информацчионной безопасности. Для процедуры анализа вымеуказанных единиц в качестве основного был выбран структурный метод.

Результаты исследования. Сопоставительный анализ структурных элементов терминополя «взлом» в сфере информацчионной безопасности в английском и итальянском языках показал, что наиболее продуктивные модели в английском языке представлены атрибутивными словосочетаниями, а в итальянском языке отмечается иирокое использование предлогов для построения многословных терминов. В структурных моделях английских терминов преобладает препозищия прилагательного по отночению к существительному, для итальянского, напротив, характерна постпозиция прилагательного.

Практическое применение результатов. Результаты исследования могут использоваться при чтении курсов лекций по лексикологии английского и итальянского языков.

Ключевые слова: информационная безопасность; терминополе; терминь-словосочетания; структурный анализ; сопоставительньій анализ. 


\section{STRUCTURAL FEATURES \\ OF TERMINOLOGICAL FIELD "HACKING" \\ IN THE FIELD OF INFORMATION SECURITY IN ENGLISH AND ITALIAN (COMPARATIVE ANALYSIS)}

\section{Dolgonovskaya L.Ya., Novikova I.N.}

The article is dedicated to the structural analysis of terminological field "hacking" in information security in the English and Italian languages. The aim of the work is to describe, compare the main structural features of the analyzed terminological units and highlight the most productive types.

Methods of work. The terminological units under study were selected using the continuous sampling method from certain scientific journals on IT security. The structural method was applied as the main one to analyze the above-mentioned units.

The results of the study. The comparative analysis of structural elements of the terminological field "hacking" in the field of information security in English and Italian has showed that the most productive models in English are attributive word combinations, but in Italian a wide use of prepositions is common for constructing multi-words terms. In the structural models of English terms adjectives are mostly found in pre-position, while postposition of adjectives is widely used in Italian multi-words terms.

Practical implications. The results of the research can be used while giving lectures on English and Italian lexicology.

Keywords: information security; terminological field; multi-words terms; structural analysis; comparative analysis.

Каждая терминосистема - неоднородное образование с достаточно сложной структурой. Структурные особенности любой терминосистемы являются важным фактором при изучении, систематизации и использовании ее терминологических единиц. Термины применяются для обозначения понятий и для определения их значений используются логические приемы и правила систематизации, классификации и выявления связей между понятиями. 
Системность терминов освещается в трудах К.Я Авербуха, М.Э. Ахметова, М.Н. Володина, С.В. Гринева, В.П. Даниленко, Т.Л. Канделаки, В.М. Лейчика, В.А Татаринова, А.А. Реформатского и др.

В.М. Лейчик в своих работах подчеркивает, что вопросы анализа и оптимизации формальной структуры термина нельзя считать решенными прежде всего потому, что далеко не все современные способы терминообразования рассмотрены в достаточной степени, а также, потому что применение исключительно лингвистических методов лексикологического и словообразовательного анализа не позволяет давать исчерпывающие рекомендации по достижению оптимальной структуры и оптимальной длины термина [6, с. 26].

Л.Я. Долгоновская отмечает, что структурные составляющие терминологических единиц имеют определенные значения, известные специалистам определенных областей знаний. [4, с. 137].

Анализируемая терминология в сфере информационной безопасности представлена разноструктурными лексическими единицами. В синтактическом аспекте термины классифицируются по структурным типам (простые, аффиксальные, сложные и словосочетания с дальнейшим более детальным подразделением вплоть до структурных моделей) [3].

Согласно классификации С.В. Гринева выделяются два основных вида лексических единиц:

1. термины-слова (однословные единицы);

2. термины-словосочетания (многословные единицы)

Состав однословных терминов довольно разнороден, их можно разделить на три основных структурных типа:

- простые;

- аффиксальные;

- сложные [2].

В настоящем исследовании за основу берется данная классификация при анализе терминополя «взлом» в сфере информационной безопасности в английском и итальянском языках. Анализ исследуемого материала показал, что среди однословных единиц в английском и итальянском языках встречаются преимуществен- 
но аффиксальные и сложные слова. Также следует отметить, что итальянский язык помимо исконных итальянских терминов часто оперирует английскими заимствованиями. Некоторые лингвисты убеждены, что в итальянском языке англоязычные термины занимают доминирующее положение по отношению к итальянским. Это объясняется несколькими факторами:

1. Итальянские варианты оказываются длиннее (из-за использования предложных сочетаний).

2. Специалисты уже привыкли работать с английскими терминами и не хотят пользоваться итальянскими.

3. Английские термины отличаются коммуникативной лабильностью.

4. Зачастую английские термины обладают прозрачной семантикой, что не всегда проявляется у соответствующих им итальянских терминов [8].

Рассмотрим аффиксальные термины в английском и итальянском языках. К данному типу относятся аффиксальные слова, образованные с помощью суффиксов:

-ware: spyware, ransomware

-ing: phishing, sniffing

Данные термины используются как в английском, так и в итальянском языках - они являются интернациональными.

Следующая группа представлена сложными словами, состоящими из двух и более корней. Как отмечает Э.А. Зоидзе, одним из самых продуктивных способов словообразования в современном английском языке является словосложение, а именно контаминация, блендинг [5, с. 84-85]. Собственно, сложные слова в английском языке также представляют интерес для исследователей, поскольку графически они не только могут быть оформлены различными способами (как единая лексема (dishwasher), через дефис (shoe-shop) или раздельно (writing table)), но и мотивированность всей лексемы может быть непрозрачной, т.е. значение сложного слова может не складываться из семантики его компонентов [7]. В ходе анализа было выявлено, что к данному структурному типу относятся следующие лексические единицы в ан- 
глийском и итальянском языках: cyberthreat, backdoor, keylogger, что подчеркивает их интернациональный характер.

Наряду с вышеупомянутыми группами в данной работе значительное количество терминов представлено в виде словосочетаний, входящих в группу многословных терминов. Словосочетание представляет собой синтаксическую конструкцию, образующуюся на основе подчинительных связей: согласования, управления и примыкания. В словосочетание полностью переносятся все те отношения, те общие и частные, более конкретные значения, которые возникают при подчинительной связи: эти отношения представляют собой значения словосочетаний $[1$, с. 34]. Поскольку большинство терминов представлены терминами-словосочетаниями (от 60 до 90\% терминов в зависимости от предметной области), то следует описать, что они собой представляют. Терминосочетание состоит из главного (чаще всего существительное) и зависимого слова (прилагательное, причастие или существительное). Структурный анализ данных терминологических единиц позволил выявить характерные модели, присущие английскому и итальянскому языкам. В английской терминологии чаще всего встречается атрибутивный вид связи (отношение между определяемым словом и определением) без помощи предлога. Например, passive attack, где attack - главное, a passive - зависимое слово.

Самые продуктивные структурные модели английского языка представлены в Таблице 1.

Таблицуа 1.

Самые продуктивные структурные модели в английском языке

\begin{tabular}{|c|c|c|}
\hline $\mathbf{N}+\mathbf{N}$ & $\mathbf{A d j}+\mathbf{N}$ & $\mathbf{A d j}+\mathbf{N}+\mathbf{N}$ \\
\hline birthday attack & blended threat & advance fee fraud \\
\hline dictionary attack & passive attack & brute force attack \\
\hline fork bomb & & Evil Twin attack \\
\hline identity theft & & watering-hole attack \\
\hline logic bomb & & \\
\hline vampire tap & & \\
\hline virus hoax & & \\
\hline
\end{tabular}


В итальянском языке наблюдается широкое использование предлогов при образовании словосочетаний. Рассмотрим значение некоторых предлогов. Целесообразно отметить, что склонение имен существительных в итальянском языке, изменяющихся лишь по числам, осуществляется с помощью предлогов (di, a, da, in, su и др.). Средний род как таковой отсутствует. Имени обычно сопутствует артикль - определенный (il, 1a, 1o, 1', i, gli, le), развившийся из латинского местоимения ille, или неопределенный (un, una, uno, un), развившийся из латинского числительного unus. Многие предлоги сливаются с определенным артиклем в одно целое.

Прилагательные, в свою очередь разделяются на два класса: к первому относятся прилагательные с разными окончаниями для мужского и женского рода (attacco - атака, minaccia - угроза), ко второму - с общим окончанием для обоих родов (grande - большой, большая). Наиболее продуктивные структурные модели словосочетаний наглядно показаны в Таблице 2.

Таблицуа 2.

Наиболее продуктивные структурные модели словосочетаний В итальянском языке

\begin{tabular}{|c|c|}
\hline сущ + предлог + сущ/прил & сущ + прил \\
\hline attacco a dizionario & attacco passivo \\
\hline attacco del compleanno & bomba fork \\
\hline attacco di forza bruta & bomba logica \\
\hline attacco Evil Twin & minaccia cibernetica \\
\hline attacco watering-hole & minacce combinate \\
\hline controllo di accesso & \\
\hline spine a vampiro & \\
\hline truffa alla nigeriana & \\
\hline uomo nel mezzo & \\
\hline
\end{tabular}

На наш взгляд, наиболее интересными для анализа представляются многокомпонентные (2 и более терминов в составе словосочетания) англоязычные терминологические словосочетания. Их особенность проявляется в неполной эквивалентности соответствующих им итальянских терминов. 
birthday attack $(\mathrm{N}+\mathrm{N})$

attacco del compleanno $(\mathrm{S}+$ prep $+\mathrm{S})$

* полная эквивалентность; в итальянском варианте проявляется характерная особенность языка: используется сложный предлог del (слияние предлога di + определенного артикля il) для связи элементов терминосочетания; в английском языке слово «birthday» очевидно разбивается на два компонента, тем не менее это слово употребляется как единое целое, в данном случае, существительное);

brute force attack $(\mathrm{Adj}+\mathrm{N}+\mathrm{N})$

attacco di forza bruta $(\mathrm{S}+$ prep $+\mathrm{S}+\mathrm{Agg})$

* частичная эквивалентность; в английском языке связь элементов беспредложная; в итальянском языке для связи элементов используется предлог di, выражающий принадлежность.

Таким образом, выделены такие структурные типы терминов: однословные, представленные аффиксальными и сложными типами, и многословные, включающие в себя термины-словосочетания. Проанализировав аффиксальные и сложные термины, можно сделать вывод, что они универсальны в английском и итальянском языках, т.к. происходит полное заимствование из английского языка. По этой причине представленные в работе однословные термины абсолютно идентичны по структуре и узусу. Сопоставительный анализ многословных терминов показал, что в итальянском языке, в отличие от английского, наблюдается широкое использование предлогов как связующих элементов словосочетания, что подчеркивает их сложную структуру. Для английского языка характерен атрибутивный тип словосочетаний. Следует также подчеркнуть, что в многословных итальянских терминах отмечается частичное заимствование, и при этом, в большинстве случаев главное слово является интернационалимом, что обеспечивает прозрачность семантики (attacco del compleanno, где attacco - главное слово).

\section{Сиисок литературы}

1. Валгина Н.С. Синтаксис современного русского языка. М.: Высшая школа, 2003. 416 c. 
2. Гринев-Гриневич С.В. Терминоведение. М.: Академия, 2008. 304 с.

3. Гринев С.В., Сорокина Э.А. Основы семиотики. М.: Флинта, Наука, 2012. $256 \mathrm{c}$.

4. Долгоновская Л.Я. Структурные особенности англоязычной терминологии информационной безопасности // Социальные и гуманитарные науки на Дальнем Востоке. Хабаровск, 2017. Т. 14. № 1. C. $137-139$.

5. Зоидзе Э.А. К вопросу о соотношении контаминации и словосложения и о современных тенденциях словообразования в английском языке // Актуальные вопросы современной лингвистики: Материалы 4-й Всероссийской научно-практической конференции, посвященной 85-летию МГОУ и 70-летию ИЛиМК / Отв. ред. М.Н. Левченко. М.: МГОУ, 2017. С. 83-88.

6. Лейчик В.М. Терминоведение: предмет, методы, структура. Изд. 2-е, испр. и доп. М.: Изд-во ЛКИ, 2007. 254 с.

7. Матвеева Е.Е. Специфика акцентуальной структуры сложных слов в английском языке (на материале BBC World News) // Современные гуманитарные исследования. М., 2019. № 1 (86). С. 65-68.

8. Молнар А.А. Особенности формирования терминосистемы информационных технологий // Вестник МГЛУ. 2011. № 620. URL: https://cyberleninka.ru/article/n/osobe (дата обращения: 05.10.2020).

\section{References}

1. Valgina N.S. Sintaksis sovremennogo russkogo yazyka [Contemporary Russian syntaxis]. Moscow: Vysshaya shkola, 2003. 416 p.

2. Grinev-Grinevich S.V. Terminovedenie [Terminology studies]. Moscow: Academy, 2008. 304 p.

3. Grinev S.V., Sorokina E.A. Osnovy semiotiki [Semiotics basics]. Moscow: Flinta, Nauka, 2012. 256 p.

4. Dolgonovskaya L.Ya. Strukturnye osobennosti angloyazychnoj terminologii informacionnoj bezopasnosti [Structure peculiarities of English information security terminology]. Social'nye i gumanitarnye nauki na Dal'nem Vostoke. Khabarovsk, 2017. V. 14. № 1. P. 137-139. 
5. Zoidze E.A. K voprosu o sootnoshenii kontaminacii i slovoslozheniya i o sovremennyh tendenciyah slovoobrazovaniya $\mathrm{v}$ anglijskom yazyke [On the correlation of contamination and word composition in English]. Aktual'nye voprosy sovremennoj lingvistiki]: Materialy 4-j Vserossijskoj nauchno-prakticheskoj konferencii, posvyashchennoj 85-letiyu MGOU i 70-letiyu ILiMK [Topical issues of modern linguistics: Materials of the 4th All-Russian Scientific and Practical Conference dedicated to the 85th anniversary of MGOU and the 70th anniversary of ILiMK] / ed. M.N. Levchenko. Moscow: MGOU, 2017. P. 83-88.

6. Lejchik V.M. Terminovedenie: predmet, metody, struktura [Terminology studies: subject, methods, structure]. Izd. 2-e, ispr. i dop. Moscow: LCI Publ., 2007. 254 p.

7. Matveeva E.E. Specifika akcentual'noj struktury slozhnyh slov $\mathrm{v}$ anglijskom yazyke (na materiale BBC World News) [Specifics of the accentual structure of English complex words]. Sovremennye gumanitarnye issledovaniya. Moscow, 2019. No 1 (86). P. 65-68.

8. Molnar A.A. Osobennosti formirovaniya terminosistemy informacionnyh tekhnologij [Formation specifics of information technology term system]. Vestnik MGLU. 2011. No 620. URL: https://cyberleninka. $\mathrm{ru} /$ article/n/osobe

\section{ДАННЫЕ ОБ АВТОРАХ}

Долгоновская Лилия Яковлевна, ассистент

Государственное автономное образовательное учреждение выстего образования города Москвы «Московский городской педагогический университет»

2-ой Сельскохозяйственньй проезд, 4, к. 1, г. Москва, 129226 , Российская Федерации dolgonovskaya@list.ru

Новикова Ирина Николаевна, кандидат филологических наук, старший преподаватель 
Федеральное государственное бюджетное образовательное учреждение высшего образования «Российский государственный университет правосудия»

ул. Новочеремушкинская, 69, г. Москва, 117418, Российская Федераичя

irkaminskaya@yandex.ru

\section{DATA ABOUT THE AUTHORS}

Dolgonovskaya Lilia Yakovlevna, Assistant

Moscow City Pedagogical University

4, building 1, 2nd Agricultural proezd, Moscow, 129226, Russian Federation

dolgonovskaya@list.ru

Novikova Irina Nikolaevna, Candidate of Philology, Senior Lecturer Russian State University of Justice 69, Novocheremushkinskaya Str., Moscow, 117418, Russian Federation

irkaminskaya@yandex.ru 